\title{
Factors influencing the characteristics and distribution or surface organic matter in the Pacific-Atlantic connection
}

\author{
Facundo Barrera ${ }^{\mathrm{a}, *}$, Rubén J. Lara a ${ }^{\text {, Bernd Krock }}{ }^{\mathrm{b}}$, John Edison Garzón-Cardona ${ }^{\mathrm{a}}$, Elena Fabro ${ }^{\mathrm{c}}$, Boris P. Koch b,d \\ a Instituto Argentino de Oceanografia (IADO), Universidad Nacional del Sur (UNS)-CONICET, La Carrindanga km 7.5, 8000 Bahía Blanca, Argentina \\ ${ }^{\mathrm{b}}$ Alfred Wegener Institut-Helmholtz Zentrum für Polar- und Meeresforschung, Chemische Ökologie, Am Handelshafen 12, 27570 Bremerhaven, Germany \\ c División Ficología, Facultad de Ciencias Naturales y Museo, Universidad Nacional de La Plata- CONICET, La Plata, Paseo del Bosque s/n, 1900, Argentina \\ d University of Applied Sciences, An der Karlstadt 8, D-27568 Bremerhaven, Germany
}

\section{A R T I C L E I N F O}

\section{Article history:}

Received 29 March 2017

Received in revised form 5 July 2017

Accepted 14 July 2017

Available online 17 July 2017

\section{Keywords:}

Southern Patagonian shelf

Biogeochemistry

Particulate and dissolved organic matter

Stables isotopes

Modelling

\begin{abstract}
A B S T R A C T
The present work reports the first data set on particulate organic carbon (POC) and nitrogen (PON), and the highresolution modelling of their stable isotope variability in the Patagonian Cold Estuarine System (PCES), with focus on particulate organic matter (POM) origin and distribution in dependence on physical, chemical and biological parameters. POC, PON, stable carbon $\left(\delta^{13} \mathrm{C}\right)$ and nitrogen isotopes $\left(\delta^{15} \mathrm{~N}\right)$, dissolved organic nitrogen, phaeopigments, diatom, dinoflagellate and heterotrophic bacteria (HB) abundance are reported for 17 stations in different waters masses in the southern end of the Argentine shelf in late summer 2012. Most parameters denote clear differences between Beagle - Magellan Water (BMW), Subantarctic Shelf Water (SSW) and Subantarctic Water (SAW). POC and PON decreased from maxima in BMW to intermediate values in SSW and minima in SAW. There was a highly significant correlation among POC, PON and fluorescence indicators of diagenetic maturity of dissolved humic matter. This, together with the inverse correlations of salinity with POC and PON, and the wide range of C:N ratios indicate that POM in the study area is partly derived from terrestrial runoff, superimposed by autochthonous components from plankton of different life stages. HB abundance was significantly correlated with POC and dissolved organic matter (DOM), likely reflecting a resource control of HB and a significant contribution of bacterial biomass to POM in the nanoparticle fraction. The direct relationship between HB and dissolved humics suggests bacterial uptake of DOM fractions otherwise considered refractory.

POM complexity was reflected in a wide variation of $\delta^{13} C$, despite the narrow temperature range of this region. The variability of stable isotopes of POC could be accounted for by a model with a degree of detail hitherto not reported in the literature. A multiple regression including $\mathrm{C}: \mathrm{N}$ ratio, ammonium and the quotient between log abundance of diatoms, dinoflagellates and $\mathrm{HB}$ explained $92 \%$ of $\delta^{13} \mathrm{C}$ variance, mostly produced by ammonium. Despite the strong effect of ammonium on $\delta^{13} \mathrm{C}, \delta^{15} \mathrm{~N}$ variability was largely explained by a strong inverse relationship with the fraction of unutilized nitrate, suggesting dominance of nitrate uptake. However, the proportion of presumably isotopically heavier ammonium derived from continental runoff in the marine $\delta^{15} \mathrm{~N}-\mathrm{POM}$ pool is unknown and requires investigation of the isotopic composition of dissolved inorganic nitrogen in the PCES.

The presented new information and its comparison with data from other sectors of the Argentine shelf constitute a contribution to an approach for the understanding of the organic matter dynamics that can be potentially expanded to the entire Southwest Atlantic.
\end{abstract}

(C) 2017 Elsevier B.V. All rights reserved.

\section{Introduction}

A sound understanding of the driving forces of dissolved (DOM) and particulate organic matter (POM) variability is essential to improve the current knowledge of carbon and nitrogen dynamics, particularly where continental and oceanic inputs occur in hydrographically complex environments. On a global scale, the amount of carbon in DOM in seawater is 20 times higher than in POM (Sharp, 1973). POM comprises living and

\footnotetext{
* Corresponding author.

E-mail address: fbarrera@criba.edu.ar (F. Barrera).
}

non-living matter, including microalgae, bacteria, detritus, fecal pellets, and clays (Volkman and Tanoue, 2002). The pool of non-living POM is about 10 times higher than plankton biomass and is dominated by complex organic molecules that are difficult to decompose (Benner and Kaiser, 2003).

Alteration of POM by microbes is particularly important in estuaries, where it represents a significant source of nutrients for adjacent coastal ecosystems (Mayer et al., 1988; Rabalais et al., 1996). DOM also plays a key role in bacterial production and microbial food web processes in coastal ecosystems (Azam and Hodson, 1977). It acts as a substrate supporting heterotrophic bacterial (HB) activity (Carlson, 2002 and 
references therein). The factors controlling its transfer, production, removal and accumulation in estuarine environments have therefore both biogeochemical and ecological significance. Determining organic matter sources (McCallister et al., 2006a, 2006b), and the factors regulating its production, consumption and transformation in coastal and oceanic waters is critical for improving our knowledge on the biogeochemical cycles in complex estuarine environments.

In this context, the Patagonian Cold Estuarine System (PCES), in the southern end of the Argentine shelf, is particularly relevant for its hydrographic complexity, high biologic productivity, freshwater inputs, and as link between oceans, particularly when trying to understand the main biogeochemical mechanisms and the sources of biogenic carbon (C) and nitrogen $(\mathrm{N})$. The PCES is part of the Pacific-Atlantic system interconnected by the Cape Horn current, which transports low-salinity water from the Southeast Pacific (Antezana, 1999; Acha et al., 2004), and continues as the Malvinas Current (Longhurst, 1998), which delivers oceanic nutrient-rich Subantarctic Waters (SAW) to the Argentine shelf (Silva and Neshiba, 1979).

Studies on the biogeochemical dynamics of organic matter in the Southwestern Atlantic are scarce, and the spatio-temporal variability of bulk POM and DOM is largely unknown. In fact, to date there are few available publications addressing tracers of suspended POM, such as stable carbon $\left(\delta^{13} \mathrm{C}\right)$ and nitrogen $\left(\delta^{15} \mathrm{~N}\right)$ isotopes (Lara et al., 2010), dissolved organic carbon (DOC) and fluorescent DOM (Garzón-Cardona et al., 2016) in Argentine shelf and adjacent oceanic waters. The latter work stressed the importance of continental runoff on the productivity of waters of the Beagle Channel, focusing on the sources of ammonium and DOC of this system. It also tested the hypothesis that ammonium derived from wet deposition or continental runoff could explain negative $\delta^{15} \mathrm{~N}$ values reported for this area in previous studies (Lara et al., 2010), but did not further investigate the sources of isotopic variability. Based on the interaction of Subantarctic waters with freshwater inputs from the SE Pacific, and relationships between DOM fluorescence properties and inorganic nutrient distributions (Garzón-Cardona et al., 2016) described a zonation of the region in Beagle Channel, coastal and oceanic waters.

The complexity of this environmental setting allows the assumption that properties of the water masses also play a major role in the characteristics of POM. Thus, the current study has two main objectives: first, the zonal characterisation of POM properties as dependent on physical and chemical parameters, and second, the understanding of the isotopic variability of organic matter in the region.

To our knowledge, the present work reports the first data set of particulate organic carbon (POC) and nitrogen (PON) distribution in the PCES, with focus on POM origin and distribution, as well as the modelling of its isotopic variability $\left(\delta^{13} \mathrm{C}\right.$ and $\left.\delta^{15} \mathrm{~N}\right)$. For this purpose, plankton size fractions were studied taxonomically and functionally; and the influence of oceanographic properties, chlorophyll, DOM features and inorganic nutrient concentration patterns reported by Garzón-Cardona et al. (2016) were also included in this analysis.

\section{Materials and methods}

\subsection{Study area and sample collection}

During the austral autumn, from March 27th to April 14th 2012, surface water samples were collected on board of $F / B$ Don Pedro and $R / V$ Puerto Deseado during the expedition IADO 0312 and PATAGONIA AUSTRAL-2012. For clarity, we used in this work an ordinal numbering for the seventeen sampling stations covering the Beagle-Drake geographical area (Fig. 1). Water depths ranged from $80 \mathrm{~m}$ in the inner part of the Beagle Channel to $2300 \mathrm{~m}$ in the open ocean. At all stations, continuous temperature and salinity (CTD) profiles were recorded.

An aliquot of $250 \mathrm{~mL}$ of sea water from the Niskin bottle samples from each station was fixed with acidic Lugol's iodine solution for determination of total plankton community composition and quantitative analyses. Diatoms and dinoflagellates cells were enumerated with a phase contrast Leica DMIL LED inverted microscope according to the procedures described by Utermöhl (1958). Subsamples of $50 \mathrm{~mL}$ were settled for $24 \mathrm{~h}$ in a composite sedimentation chamber. Additionally, plankton samples were collected by vertical net tows through the upper $20 \mathrm{~m}$ of the water column with a $20 \mathrm{~mm}$-mesh Nitex net of $60 \mathrm{~cm}$ diameter. An aliquot of $100 \mathrm{~mL}$ of net sample was fixed with acidic Lugol's iodine solution for diatoms and dinoflagellates taxonomic analysis.

For picoplankton abundance determination, $3 \mathrm{~mL}$ of surface seawater sample were preserved with $1 \%$ paraformaldehyde $+0.05 \%$ glutaraldehyde (final concentration), frozen and stored at $-20^{\circ} \mathrm{C}$. The samples were later thawed, stained with SYBR-Green I (SYBR-I, 1:30 dilution of commercial stock; Invitrogen, USA; lex $\lambda 495 \mathrm{~nm}$, lem $\lambda 525 \mathrm{~nm}$ ) diluted in dimethyl sulfoxide (DMSO, Merck, Germany) (Marie et al., 2005). Ten microliters of fluorochrome was added to $1 \mathrm{~mL}$ of bacterial sample. Samples were incubated in the dark for $15 \mathrm{~min}$ at room temperature. Cell counts were performed with a flow cytometer (A40, Apogee Flow Systems, UK) equipped with an argon laser ( $488 \mathrm{~nm}$ ). Cells were counted following Marie et al. (2005). Briefly, HB were detected by their signature in a plot of side scatter (SSC) versus green fluorescence (FL1). Autotrophic picoplankton (AP) was detected by direct fluorescence in a plot of SSC versus red fluorescence (FL3).

\subsection{Biogeochemical bulk parameters}

POM and DOM samples were obtained from surface water between 3 and $10 \mathrm{~m}$ using Niskin bottles. Mostly $3 \mathrm{~L}$ of each sample was passed through $200 \mu \mathrm{m}$ mesh to remove large zooplankton, filtered (max. 300 mbar) using precombusted $\left(4 \mathrm{~h}, 450^{\circ} \mathrm{C}\right)$ glass fiber filters $(\mathrm{GF} / \mathrm{F}$, Whatman). The nominal $0.7 \mu \mathrm{m}$ pore-size of GF/F filters was the operational limit for separating POM from DOM in this study. The filtered water was kept frozen $\left(-20^{\circ} \mathrm{C}\right)$ until determination of DOM fluorescence and dissolved organic nitrogen (DON) concentration.

POC, PON, stable C and $\mathrm{N}$ isotope ratio analyses were carried out with a mass spectrometer (Delta Plus, Thermo Finnigan) coupled to $\mathrm{CN}$ Analyser Eurovector EA3000 element analyzer according to Verado et al. (1990). Inorganic C was removed by acidification with $0.1 \mathrm{HCl}$ and dried again at $50{ }^{\circ} \mathrm{C}$. Accuracy was checked and tolerances corrected by measuring internal standards and automated baseline correction after a set of five samples, with analytical precision $\mathrm{CN}$ analyses $\leq 1.0 \%$. Results were normalized to the Pee Dee Belemnite (PDB) (Fry and Sherr, 1984) and atmospheric $\mathrm{N}_{2}$ standards calculating isotope ratios (R) (Eq. (I)), given as \% deviation from the standard value $\delta^{13} \mathrm{C}$ and $\delta^{15} \mathrm{~N}$ (Eq. (II)), with the analytical precision $\leq 0.5 \%$.

$$
\begin{aligned}
& R=\frac{{ }_{0}^{13} \mathrm{C}}{{ }_{0}^{12} \mathrm{C}}{ }_{0} \frac{15}{0_{0}^{14} \mathrm{~N}} \text { and } \\
& \delta(\% \circ)=\left[\left(\frac{R_{\text {sample }}}{R_{\text {standard }}}\right)-1\right]^{*} 1000
\end{aligned}
$$

Pigment extraction on duplicate filter samples was performed in $10 \mathrm{~mL} 90 \%$ acetone during $24 \mathrm{~h}$ at $4{ }^{\circ} \mathrm{C}$ in darkness. After acidification with $0.1 \mathrm{~N} \mathrm{HCl}$ phaeopigments were quantified by fluorometry (HolmHansen et al., 1965).

Dissolved inorganic nutrients (nitrate, nitrite, phosphate, silicate and ammonium), were determined spectrophotometrically with an autoanalyzer (Evolution III, Alliance Instruments) according to standard methods for seawater analysis (Kattner and Becker, 1991; GarzónCardona et al., 2016). DOC and total dissolved nitrogen (TDN) was quantified in duplicate by high temperature catalytic oxidation and subsequent non-dispersive infrared spectroscopy and chemoluminescence detection (TOC-VCPN, Shimadzu), (Koroleff, 1983) and substracting inorganic nitrogen species previously determined by Garzón-Cardona et al. (2016), 


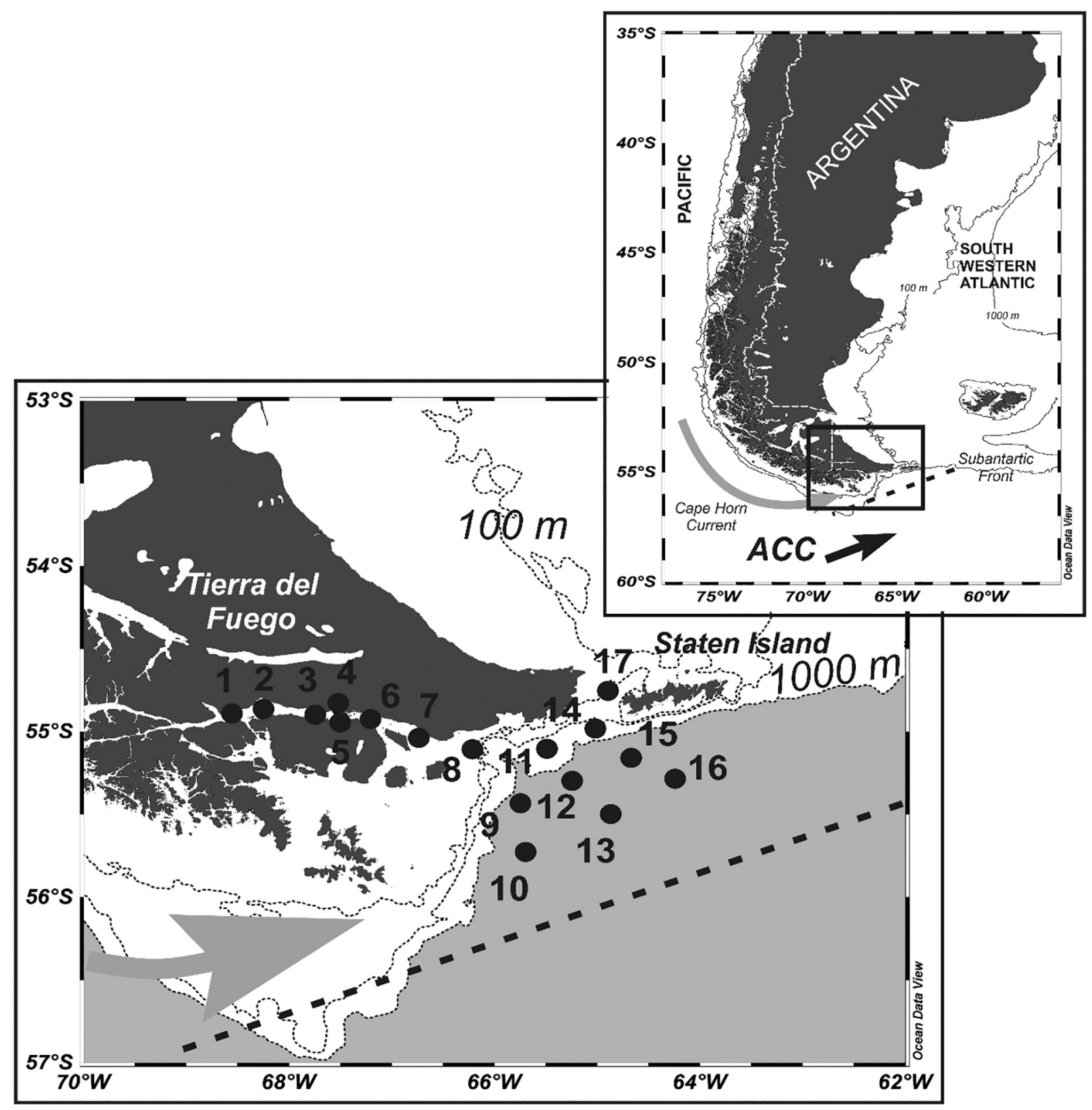

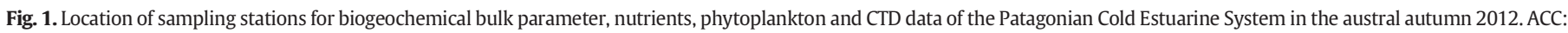
Antarctic Circumpolar Current. Dashed line, Subantartic front.

with a relative error of about $4 \%$. If the standard variation or the coefficient of variation exceeded $0.1 \mu \mathrm{M}$ or $1 \%$, respectively, up to two additional analyses were performed and outliers were eliminated.

\subsection{Oceanographic variables, data processing and statistical treatments}

Data on temperature, salinity, and water depth were obtained using a CTD (Sea Bird model 911 plus with General Oceanic rosette) and calibrated with a final precision of 0.05 in salinity and $0.02{ }^{\circ} \mathrm{C}$ in temperature. All parameters were processed and displayed using Ocean Data View Software (ODV-version 4.6, Schlitzer, 2010).

The degree of statistical significance of the spatial distribution was estimated by applying a one-way ANOVA test. In all cases, normality (Shapiro-Wilk) and homogeneity (Levene) of variances were tested previously. Whenever needed, subsequent comparisons of unequal samples were made by using a Tukey test.

In order to gain a deeper insight into the main driving forces of biogeochemical bulk parameters variability, with emphasis in the stable isotopic signature, we used our own data set, as well as from the literature, such as inorganic nutrients, DOC, optical properties of DOM (humification index, HIX) and its fluorescent fraction (FDOMc) (GarzónCardona et al., 2016) and stable C and N isotopic data of POM (Lara et al., 2010). Simple, multiple linear and exponential regressions were applied to isotopic data to assess their response to change in biogeochemical parameters. The y-intercept and slope significance of simple linear regression lines was tested by the two-tailed Student $t$-test and the difference between slopes with ANOVA sum of squares (F-test).

\section{Results}

\subsection{Hydrographic conditions}

Salinity increased from 29.31 in coastal waters to 34.26 near the continental slope (Fig. 2a), in accordance with the occurrence of the three water masses in the study area: The Beagle Magellan Waters (BMW) with salinity $<33.4$, Subantarctic Shelf Water $($ SSW $)(33.4<$ S $<34.0)$ 

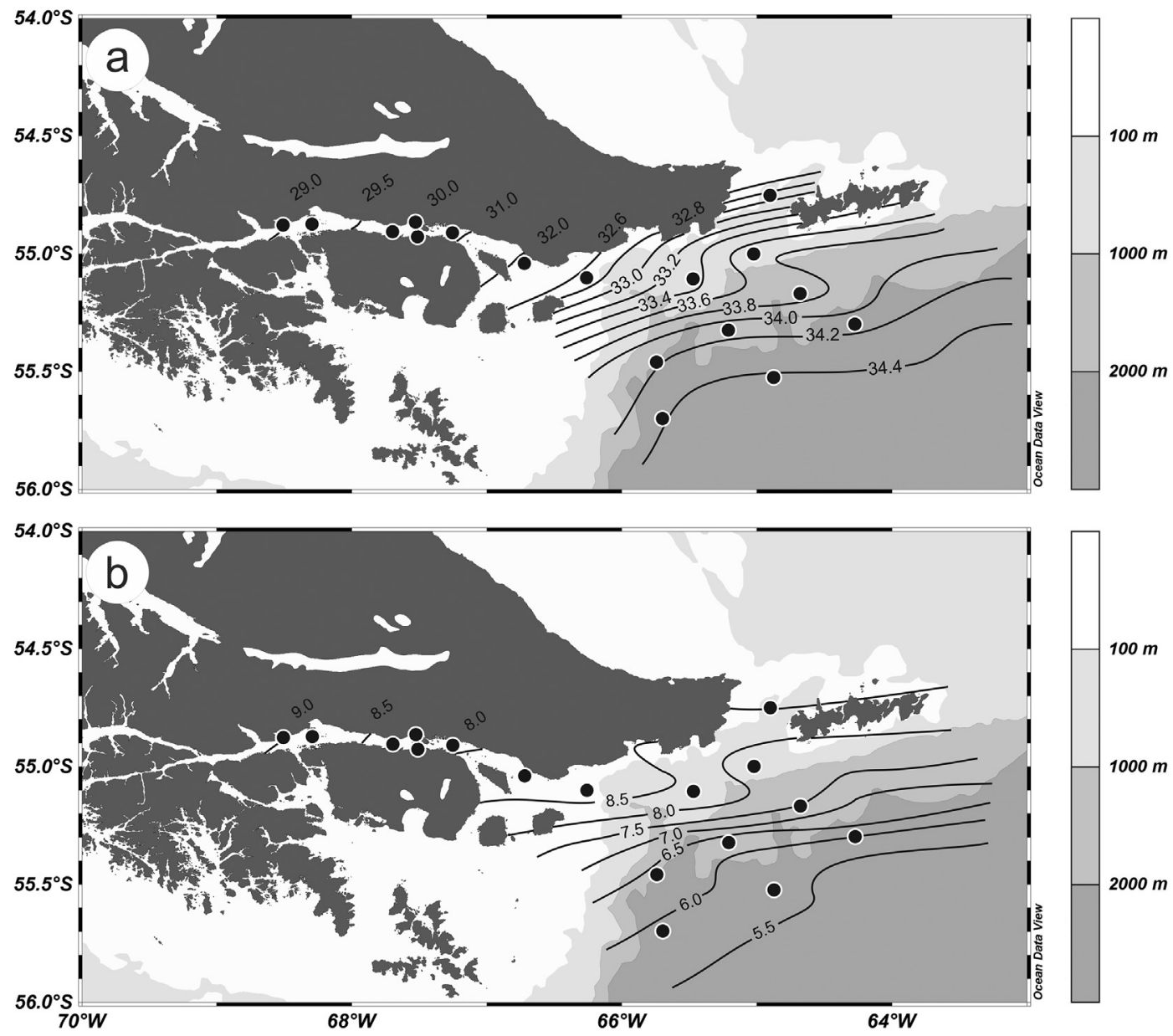

Fig. 2. Distribution of surface seawater salinity (a) and temperature (b) in the study area.

and Subantarctic Water (SAW) $(S>34.0)$. Temperature fields at the time of the cruise were horizontally and vertically relatively homogeneous (on average $7.64{ }^{\circ} \mathrm{C} \pm 1.17^{\circ} \mathrm{C}$ ) in BMW, decreasing towards the continental slope and the open ocean (Fig. 2b). The transitions of water masses are further illustrated by a T-S diagram of all stations (Fig. 3).

BMW had temperatures around $\sim 8.5^{\circ} \mathrm{C}$ and is influenced by low-salinity coastal water. In this sense, waters western of Gable Island in the Beagle Channel shows a vertical homogeneity during most of the year (Bujalesky, 2007). The relative degree of stratification stability was inferred from the relationship between the angle of the line density $(\sigma)$ and the slope of the T-S curve. Thermoclines were well established in the SSW and SAW. On average SAW was more saline, with salinities $>34.0$ and a pronounced vertical decrease of temperature was observed.

\subsection{Abundance of phytoplankton and heterotrophic bacteria}

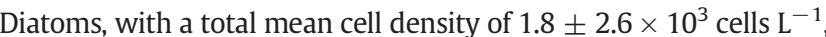
dominated in BMW representing up to $45 \%$ of total phytoplankton abundance (Fig. 4). Towards the open ocean, diatom counts decreased significantly to around $7 \%$ of the total abundance. In contrast, dinoflagel-

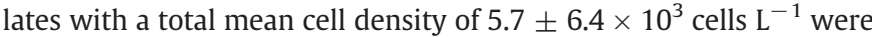
highly dominant in SSW and SAW (92\% and 93\% of total phytoplankton abundance, respectively). HB showed a total mean abundance of $1.0 \pm$ $0.8 \times 10^{6}$ cells $\mathrm{mL}^{-1}$ (Fig. 4).

\subsection{Synoptic trend of biogeochemical bulk parameters}

The main biogeochemical characteristics of each water mass as described in 3.1 are presented in Table 1. All variables showed significant

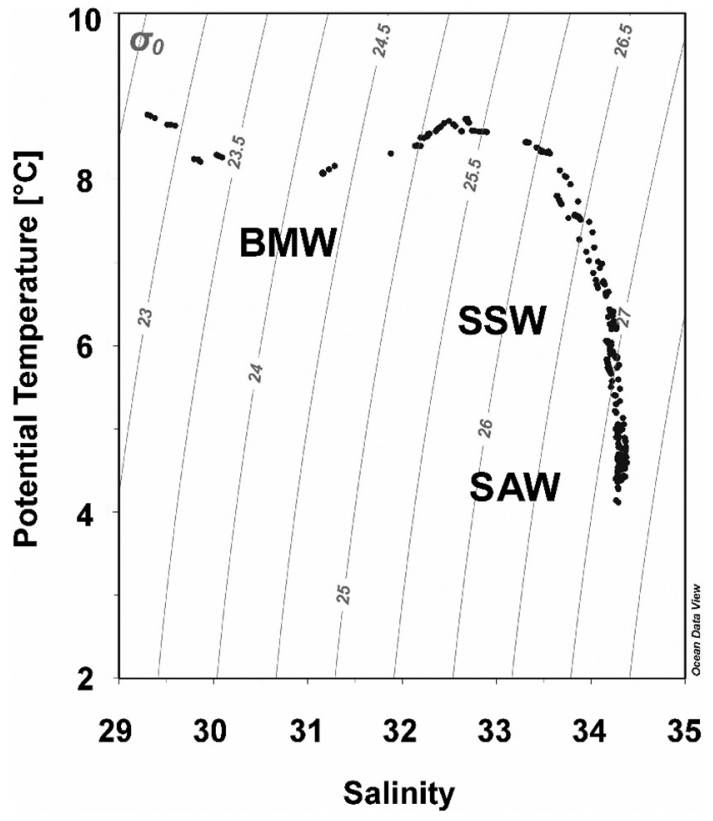

Fig. 3. T-S diagram of CTD casts of the entire expedition showing the different water masses. Beagle Magellan water (BMW), Subantarctic shelf water (SSW) and Subantarctic water (SAW). 


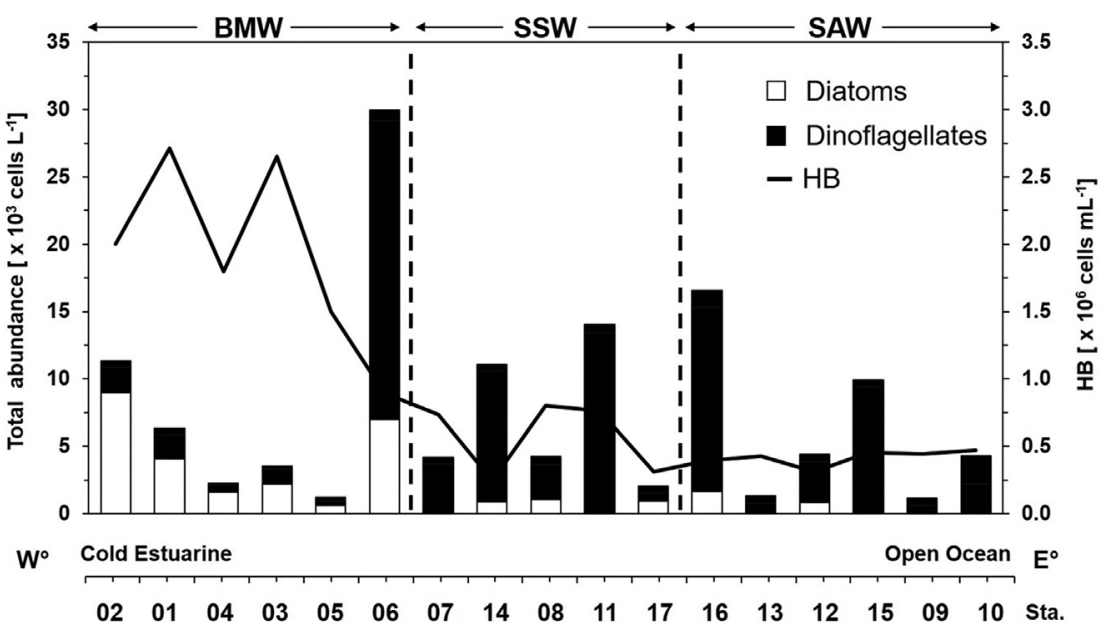

Fig. 4. Abundance of diatoms, dinoflagellates and heterotrophic bacteria (HB, black line) in different sectors from coastal to offshore.

differences $(p<0.05)$ among the three analyzed zones, except for C:N ratios.

POC concentration gradually decreased from the inner Beagle Channel with maximum values around $28 \mu \mathrm{M} \mathrm{C}$ to eastward oceanic waters with values of $5 \mu \mathrm{MC}$ (Table 1). The PON distribution pattern (Table 1) was similar to POC, with a maximum around $4 \mu \mathrm{M} N$ in the inner BMW and $0.5 \mu \mathrm{M} N$ in SAW. In contrast to the nearly linear decrease of POC concentration with salinity increase, the composition of $C$ isotopes presented a more complex pattern with $\delta^{13} \mathrm{C}$ values within a range of -24.5 to $-20.9 \%$ o (mean $-23.0 \pm 0.9 \%$ ). The $\delta^{15} \mathrm{~N}$ values decreased from BMW (6.9\%) to SAW (2.9\%) (Table 1$)$. There was a predominance of isotopically lighter POM with increasing distance to the coast. The main driving forces of the isotopic variability will be analyzed in detail later (Section 4.3.3).

The Chl $a$ values $\left(0.1-3.7 \mu \mathrm{L} \mathrm{L}^{-1}\right)$, with a decreasing tendency to the east of the BMW (Table 1), were low and comparable to those previously reported (Garzón-Cardona et al., 2016) in the same zone and season. Phaeopigment concentrations ranged $0.1-1.2 \mu \mathrm{L} \mathrm{L}^{-1}$ and were with on average $0.6 \pm 0.4 \mu \mathrm{g} \mathrm{L}{ }^{-1}$ relatively high and similar to those reported for middle and outer shelf waters during early autumn on the Argentine Shelf and waters of Northern Drake Passage (Lara et al., 2010; Krock et al., 2015).

Mean DOC and inorganic nutrient concentrations showed statistically significant $(p<0.05)$ differences among sampled areas (Table 2$)$. Nitrate, silicate and phosphate increased roughly SE in direction to the nutrientrich waters of the Antarctic Circumpolar Current (Guerrero and Piola, 1997; Paparazzo et al., 2016). Ammonium showed the opposite trend and increased to the NW, suggesting that continental runoff is the most important source of reduced inorganic nitrogen in this region (GarzónCardona et al., 2016).

\section{Discussion}

\subsection{Hydrographic conditions}

Significant differences were evident in temperature and salinity data $(p<0.05)$ between all analyzed zones. Waters with distinct salinities generated several surface fronts of different intensities on the shelf. Although we only measured surface temperature and salinity in the Beagle Channel, it can be considered as a vertically homogeneous estuary due to its shallow depths ( $<100 \mathrm{~m}$ ) (Hamamé and Antezana, 1999; Palma and Silva, 2004). The salinity gradient between BMW $(<33.4)$ and SAW (>34.0) (Bianchi et al., 1982; Palma et al., 2008), generates a front with SSW in this region. This has been previously referred to as a typical mid-shelf water mass boundary front (Sabatini et al., 2004), also named Atlantic cold estuarine front (Acha et al., 2004) east of Tierra del Fuego. However, other coastal horizontal gradients were detected at various distances from the shore $(20-30 \mathrm{~km})$ south of the island. These are likely tidal estuarine-plume type fronts, as their origin seems to be related to freshwater discharges onto the shelf as also reported by Sabatini et al. (2004).

Horizontal gradients are strong from BMW to SAW, with relatively higher temperatures $\left(\sim 9{ }^{\circ} \mathrm{C}\right)$ and less saline waters $(\sim 29)$ typical for BMW. In the SAW, the temperature decreases $\left(5.5^{\circ} \mathrm{C}\right)$ and salinity

Table 1

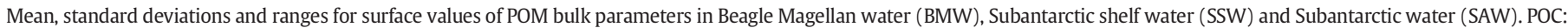

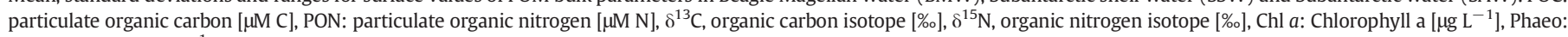
Phaeopigments $\left[\mu \mathrm{L} \mathrm{L}^{-1}\right]$. Different letters $(a, b)$ represent significant differences ( $\mathrm{n}=17$, one-way ANOVA, Tukey's test, $p<0.05$ ).

\begin{tabular}{|c|c|c|c|c|c|c|}
\hline Variable & $\operatorname{BMW}(\mathrm{n}=6)$ & $\operatorname{SSW}(\mathrm{n}=5)$ & SAW $(n=6)$ & Total $(\mathrm{n}=17)$ & $\mathrm{F}$ & $P$ \\
\hline $\mathrm{POC}$ & $\begin{array}{l}19.5 \pm 6.9 a \\
{[11.3 ; 28.3]}\end{array}$ & $\begin{array}{l}10.7 \pm 3.8 b \\
{[7.5 ; 16.7]}\end{array}$ & $\begin{array}{l}6.4 \pm 1.0 b \\
{[5.0 ; 7.6]}\end{array}$ & $\begin{array}{l}12.3 \pm 7.2 \\
{[5.0 ; 28.3]}\end{array}$ & 12.422 & 0.001 \\
\hline PON & $\begin{array}{l}2.3 \pm 1.1 a \\
{[1.0 ; 3.7]}\end{array}$ & $\begin{array}{l}0.9 \pm 0.2 b \\
{[0.6 ; 1.1]}\end{array}$ & $\begin{array}{l}0.6 \pm 0.1 b \\
{[0.5 ; 0.8]}\end{array}$ & $\begin{array}{l}1.3 \pm 1.0 \\
{[0.5 ; 3.7]}\end{array}$ & 9.587 & 0.002 \\
\hline $\mathrm{C}: \mathrm{N}$ & $\begin{array}{l}9.1 \pm 1.6 a \\
{[7.2 ; 11.0]}\end{array}$ & $\begin{array}{l}11.5 \pm 2.6 a \\
{[8.8 ; 14.9]}\end{array}$ & $\begin{array}{l}10.3 \pm 0.8 a \\
{[9.1 ; 11.5]}\end{array}$ & $\begin{array}{l}10.2 \pm 1.9 \\
{[7.2 ; 14.9]}\end{array}$ & 2.595 & 0.110 \\
\hline$\delta^{13} \mathrm{C}$ & $\begin{array}{l}-22.4 \pm 1.0 a \\
{[-23.7 ;-20.9]}\end{array}$ & $\begin{array}{l}-22.9 \pm 0.8 a b \\
{[-24.2 ;-21.8]}\end{array}$ & $\begin{array}{l}-23.8 \pm 0.5 b \\
{[-24.5 ;-23.2]}\end{array}$ & $\begin{array}{l}-23.0 \pm 1.0 \\
{[-24.5 ;-20.9]}\end{array}$ & 4.529 & 0.030 \\
\hline$\delta^{15} \mathrm{~N}$ & $\begin{array}{l}6.9 \pm 0.7 a \\
{[6.3 ; 8.0]}\end{array}$ & $\begin{array}{l}5.2 \pm 2.1 a \\
{[2.0 ; 7.3]}\end{array}$ & $\begin{array}{l}2.9 \pm 0.8 b \\
{[1.9 ; 3.8]}\end{array}$ & $\begin{array}{l}5.0 \pm 2.1 \\
{[1.9 ; 8.0]}\end{array}$ & 14.499 & 0.004 \\
\hline Chl $a$ & $\begin{array}{l}1.7 \pm 1.4 a \\
{[0.3 ; 3.7]}\end{array}$ & $\begin{array}{l}0.4 \pm 0.2 \mathrm{ab} \\
{[0.1 ; 0.5]}\end{array}$ & $\begin{array}{l}0.3 \pm 0.1 b \\
{[0.1 ; 0.5]}\end{array}$ & $\begin{array}{l}0.8 \pm 1.0 \\
{[0.1 ; 3.7]}\end{array}$ & 4.898 & 0.002 \\
\hline Phaeo & $\begin{array}{l}0.8 \pm 0.3 a \\
{[0.5 ; 1.2]}\end{array}$ & $\begin{array}{l}0.7 \pm 0.1 a \\
{[0.5 ; 0.8]}\end{array}$ & $\begin{array}{l}0.2 \pm 0.2 b \\
{[0.1 ; 0.6]}\end{array}$ & $\begin{array}{l}0.6 \pm 0.4 \\
{[0.1 ; 1.2]}\end{array}$ & 9.689 & 0.002 \\
\hline
\end{tabular}


Table 2

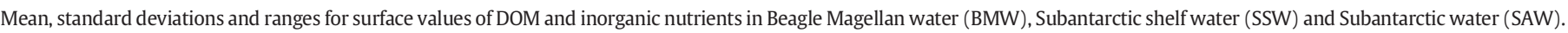

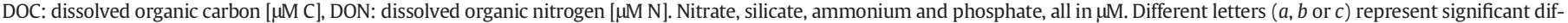
ferences ( $\mathrm{n}=14$, one-way ANOVA, Tukey's test, $p<0.05$ ).

\begin{tabular}{|c|c|c|c|c|c|c|}
\hline Variable & BMW $(n=4)$ & $\operatorname{SSW}(\mathrm{n}=4)$ & $\operatorname{SAW}(\mathrm{n}=6)$ & Total $(\mathrm{n}=14)$ & $\mathrm{F}$ & $P$ \\
\hline DOC & $\begin{array}{l}67.9 \pm 5.2 a \\
{[63.1 ; 76.4]}\end{array}$ & $\begin{array}{l}58.3 \pm 5.9 a b \\
{[50.1 ; 64.0]}\end{array}$ & $\begin{array}{l}53.3 \pm 4.8 b \\
{[46.0 ; 58.7]}\end{array}$ & $\begin{array}{l}58.9 \pm 8.0 \\
{[46.0 ; 76.4]}\end{array}$ & 7.419 & 0.009 \\
\hline DON & $\begin{array}{l}4.0 \pm 1.3 a \\
{[2.3 ; 5.9]}\end{array}$ & $\begin{array}{l}2.8 \pm 0.9 a \\
{[1.9 ; 4.3]}\end{array}$ & $\begin{array}{l}2.0 \pm 1.4 a \\
{[0.4 ; 3.6]}\end{array}$ & $\begin{array}{l}2.9 \pm 1.5 \\
{[0.4 ; 5.9]}\end{array}$ & 2.277 & 0.153 \\
\hline Nitrate & $\begin{array}{l}7.1 \pm 1.6 a \\
{[4.9 ; 8.8]}\end{array}$ & $\begin{array}{l}12.1 \pm 2.7 b \\
{[8.7 ; 16.2]}\end{array}$ & $\begin{array}{l}18.9 \pm 2.0 c \\
{[8.7 ; 16.2]}\end{array}$ & $\begin{array}{l}13.6 \pm 5.4 \\
{[4.9 ; 20.4]}\end{array}$ & 29.474 & 0.0001 \\
\hline Ammonium & $\begin{array}{l}2.6 \pm 1.1 a \\
{[1.6 ; 4.5]}\end{array}$ & $\begin{array}{l}1.2 \pm 0.6 a b \\
{[0.6 ; 2.1]}\end{array}$ & $\begin{array}{l}0.5 \pm 0.1 b \\
{[0.4 ; 0.6]}\end{array}$ & $\begin{array}{l}1.3 \pm 1.1 \\
{[0.4 ; 4.5]}\end{array}$ & 8.478 & 0.006 \\
\hline Silicate & $\begin{array}{l}1.9 \pm 0.1 a \\
{[1.8 ; 2.0]}\end{array}$ & $\begin{array}{l}2.0 \pm 0.2 a \\
{[1.7 ; 2.2]}\end{array}$ & $\begin{array}{l}3.1 \pm 0.4 b \\
{[2.4 ; 3.5]}\end{array}$ & $\begin{array}{l}2.4 \pm 0.6 \\
{[1.7 ; 3.5]}\end{array}$ & 24.845 & 0.0001 \\
\hline Phosphate & $\begin{array}{l}0.8 \pm 0.1 a \\
{[0.6 ; 0.9]}\end{array}$ & $\begin{array}{l}1.0 \pm 0.1 a \\
{[0.9 ; 1.1]}\end{array}$ & $\begin{array}{l}1.3 \pm 0.1 b \\
{[1.1 ; 1.4]}\end{array}$ & $\begin{array}{l}1.1 \pm 0.2 \\
{[0.6 ; 1.4]}\end{array}$ & 21.417 & 0.0001 \\
\hline
\end{tabular}

increases (34.4) (Fig. 2). This gradient is generated as result of the complex mixing of fresher water from the Beagle Channel, slope water, Cape Horn continental shelf and SAW (Krepper, 1977; Krepper and Rivas, 1979; Bianchi et al., 1982; Guerrero et al., 1999).

\subsection{Abundance of phytoplankton and heterotrophic bacteria}

Phytoplankton abundance showed similar values and trends as previously reported for this region in autumn (Almandoz et al., 2011; Krock et al., 2015). One of the most conspicuous features of the phytoplankton assemblage in PCES was the contrasting change of dominance between diatoms and dinoflagellates during the autumn period. Diatoms typically dominate in cold waters, in this sector extending to $57^{\circ} \mathrm{S}$ near the Polar Front (Olguín and Alder, 2004). However, in this part of the PCES the total abundance of autotrophic dinoflagellates was higher, which has also been reported by Almandoz et al. (2011).

In PCES, high abundance of phytoplankton was found at the boundaries between BMW-SSW and SSW-SAW, respectively. The former has been previously referred to mid-shelf front (Sabatini et al., 2004). In the high-nutrient low-chlorophyll areas, the algal productivity has been related to frontal systems (Lancelot et al., 2000).

\subsection{Synoptic trends of biogeochemical bulk parameters}

\subsubsection{Main driving forces of POM and DOM variability}

Correlations of POM parameters with temperature and salinity are summarized in Table 3. POC and PON showed highly significant inverse correlations with salinity and positive correlations with temperature and thus support the postulated input of DOC and inorganic nutrients (Garzón-Cardona et al., 2016) to the Pacific-Atlantic connection zone by runoff from southern Chilean fjords, which is the main source of freshwater to the Cape Horn Current, and likely also from Tierra del Fuego rivers.

POC and PON correlated significantly at all stations $(r=0.96, n=17$, $p<0.001$ ) (Fig. 5a). With exception of three stations (Sta. 12, 13, 16), DOC (Garzón-Cardona et al., 2016) and DON (this work) also correlated significantly ( $\mathrm{r}=0.85, \mathrm{n}=12, p<0.001$ ) (Fig. $5 \mathrm{~b}$ ). In both cases, the $\mathrm{y}$-intercept was significantly different from zero $\left(t_{\text {POC-PON }}=3.94\right.$, $t_{\text {DOC-DON }}=$ $19.58, p<0.001$ ). This suggests an input of carbon-rich, nitrogen-poor organic matter from subantarctic peatlands into the investigated region.

\section{Table 3}

Matrix of Pearson correlation coefficients $(p<0.001)$ between POM parameters and temperature and salinity data. n.s.: not significant.

\begin{tabular}{lll}
\hline Biogeochemical parameters & Temperature $\left[{ }^{\circ} \mathrm{C}\right]$ & Salinity \\
\hline POC & 0.70 & -0.86 \\
PON & 0.62 & -0.83 \\
C:N & n.s. & n.s. \\
\hline
\end{tabular}

POC and PON showed highly significant correlations with the DOM humification index HIX (Fig. 5c) and its fluorescent fraction, FDOMc (Fig. 5d). Since these parameters provide information on the complexity and diagenetic maturity of humic DOM based on its structure (Senesi et al., 1991; Zsolnay et al., 1999; Ohno, 2002), the direct correlations with POC and PON, as well as the inverse correlations of these with salinity further indicate that at least a fraction of POM in the study area is derived from terrestrial runoff.

HB abundance showed highly significant correlations with DOC $(\mathrm{r}=$ $0.77, \mathrm{n}=14, p<0.001)$ and particularly POC $(\mathrm{r}=0.91, \mathrm{n}=17, \mathrm{p}<0.001)$ (Fig. 5e). This can be interpreted as bottom-up, resource control of HB (e.g. Varela et al., 2003), and likely also a major contribution of bacterial biomass to $\mathrm{POC}$ in the nanoparticle fraction.

The significant correlation between HB, FDOMc and HIX (Fig. 5f) suggests that marine bacterioplankton can metabolize specific fractions of the terrigenous DOM pool that are traditionally perceived to be more resistant to biodegradation (Fellman et al., 2010).

\subsubsection{Inorganic nutrients variability}

Inorganic nutrients and their ranges in the upper BMW, SSW and SAW (Table 2) were similar to those in other cold estuaries (Cauwet and Sidorov, 1996; Kattner et al., 1999; Carmack et al., 2004; Emmerton et al., 2008) where, in general, water runoff entering the ocean is rich in organic matter and depleted in inorganic nitrogen in the inside zone (McClelland et al., 2012). The PCES is associated to the Sub-Antarctic frontal system (Acha et al., 2004), which provides a high nutrient concentration in fall (Paparazzo et al., 2016). Small fronts or eddies, associated to atmospheric anomaly (Sprintall, 2008) and west winds, can sustain nutrient reload and biological productivity in this area (Thompson and Alder, 2005).

\subsubsection{Main driving forces of isotopic variability}

The latitudinal variability of isotopic signatures in SAW has been previously analyzed on a regional scale (Lara et al., 2010). Based only on temperature, the empirical regression equation $\delta^{13} \mathrm{C}=0.6$ SST $28.7 \%$ obtained in the aforementioned work, rendered an estimated $\delta^{13} \mathrm{C}$ value of $-24.0 \%$ or the average temperature of $7.6{ }^{\circ} \mathrm{C}$ in the study region, which is in very good accordance with the average value of $-23.8 \pm 0.5 \%$ reported in the present work. However, the wide range of $\delta{ }^{13} \mathrm{C}$ values found in BMW to SAW cannot be explained by temperature variation alone $(\mathrm{r}=0.4, \mathrm{n}=17, p>0.05)$. It is worth mentioning that in the Le Maire Strait much heavier POC with $\delta{ }^{13} \mathrm{C}$ around $-20 \%$ was reported by Lara et al. (2010), in coincidence with high ammonium concentrations of around $1.5 \mu \mathrm{M}$. This underlines the potential influence of ammonium distribution on the $\delta^{13} \mathrm{C}$ variability in the region, even at high nitrate concentrations (see below).

In order to obtain a deeper insight into the driving forces of isotopic signature variability, we focused on parameters whose variation had been already found to significantly influence $\delta^{13} \mathrm{C}$ in the Southwestern 

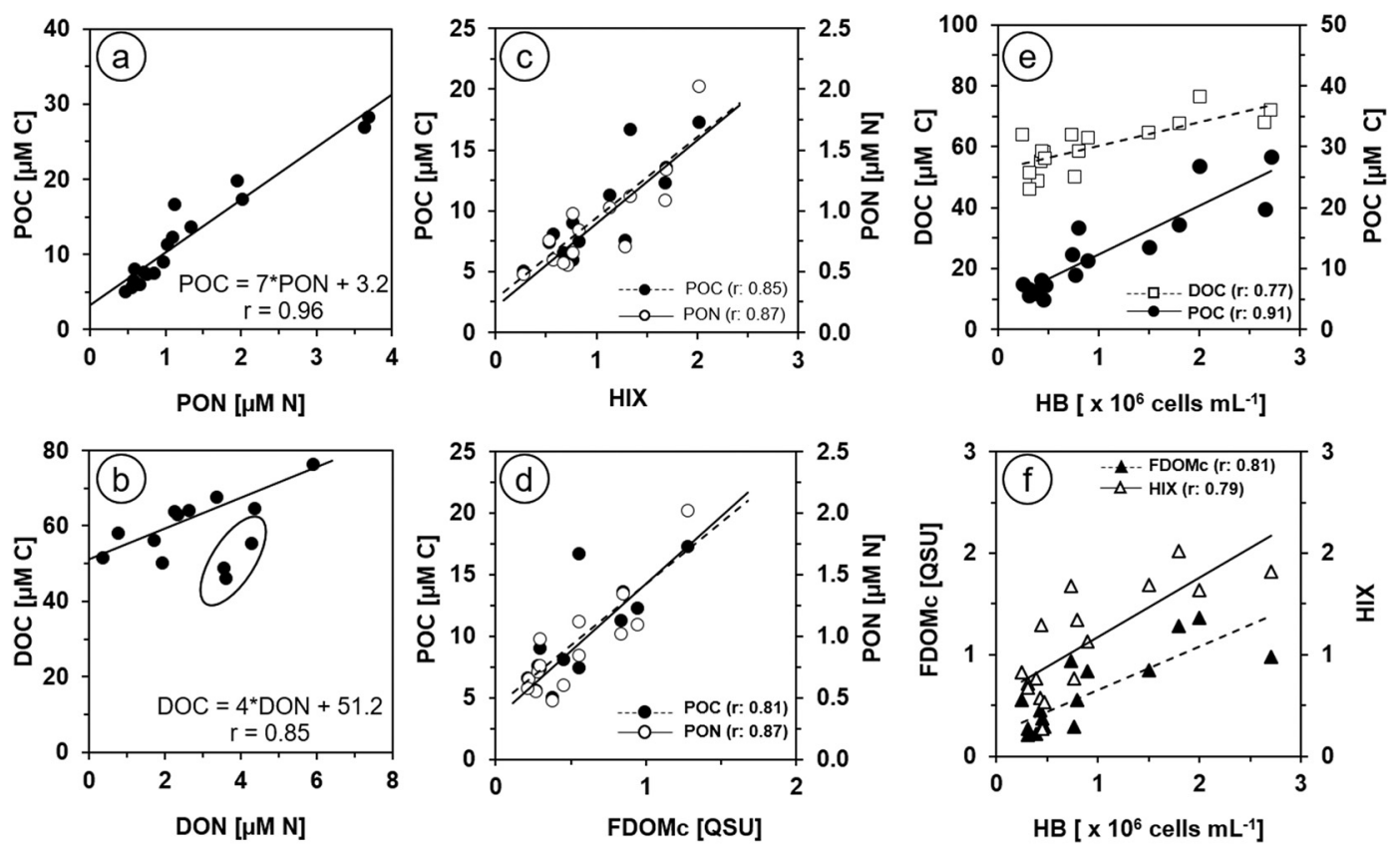

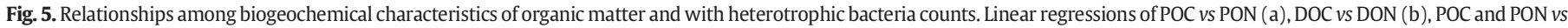

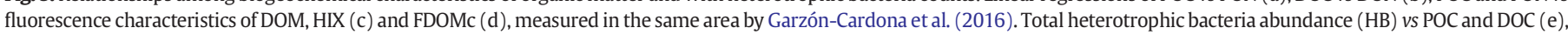
and $v s$ FDOMc and HIX (f).

Atlantic, namely POC and ammonium, with a wide variation range in the study area. Further, we included PON, the POC:PON ratio and information about the composition of the planktonic community, since the isotopic signature of plankton changes with their physical and chemical environment, notably with the concentrations of nutrients (Vuorio et al., 2006). Nutrient values for this analysis were taken from GarzónCardona et al. (2016).

During data analysis, we observed that the multiple regression $\delta^{13} \mathrm{C}$ vs POC and ammonium rendered a significant correlation of $\mathrm{r}=0.75$. However, POC and ammonium were not independent and showed a highly significant correlation of $\mathrm{r}=0.97$. Although this result precluded the simultaneous use of the mentioned parameters as independent variables in the multiple regression, it also highlighted the importance of ammonium for biomass production in PCES, in comparison to nitrate, which showed a lower and inverse correlation with POC $(r=-0.78)$.

While testing the influence of the abundance of the individual plankton groups on $\delta^{13} \mathrm{C}$, we observed cross correlations between abundances of diatoms and HB. Thus, in order to circumvent this limitation and at the same time preserve the ecological information, we calculated a coefficient ( $\varphi$, Eq. (III) see below) roughly expressing the relative abundance of "autotrophs" (including dinoflagellates, which can behave as mixotrophs) and heterotrophs, in order to be able to use the information about the composition of the planktonic community, reflecting the growth conditions for algae as well as the availability of organic substrates for bacterial growth (Azam et al., 1983). Following a similar reasoning, we replaced POC by POC:PON ratio which gives information about its origin and avoids the high correlation between POC and ammonium.

Thus, we applied multiple regressions of $\delta^{13} \mathrm{C}$ relative to $\mathrm{C}: \mathrm{N}$ ratio, inorganic nutrients and $\varphi$, as relation between the normalized abundance of diatoms, dinoflagellates and heterotrophic bacteria:

$\varphi=\frac{\log \text { Diatoms }+\log \text { Dinoflag }}{\log H B}$

The most relevant results of the different regression arrays tested for modelling our $\delta^{13} \mathrm{C}$ data following Dehairs et al. (1997) are summarized in Table 4, including only the minimum amount of parameters that had proofed influence on $\delta^{13} \mathrm{C}$ of POM, did not cross-correlate with each other, and explained the highest amount of $\delta^{13} \mathrm{C}$ variance.

The ANOVA of the multiple regressions indicated a significant improvement in the prediction of the dependent variable $(\mathrm{F}=31.05, \mathrm{n}=$ $12, p<0.001$ ) with the incorporation of each independent variable shown.

The combination of the best-fit and more realistic distribution of predicted values was obtained with $\mathrm{C}: \mathrm{N}$ ratio of $\mathrm{POM}$, ammonium and $\varphi$ in a multiple regression equation that explained $92 \%$ of the variance of the observed $\delta^{13} \mathrm{C}$ values.

$\delta^{13} \mathrm{C}=-26.6+0.4 \mathrm{C}: \mathrm{N}+0.8 \mathrm{NH}_{4}^{+}-2.0 \varphi$

The $\delta^{13} \mathrm{C}$ values predicted by Eq. (IV) are compared to be measured ones in Fig. 6.

The ecological meaning of the used parameters, in terms of explaining most of the variance of the $\delta^{13} \mathrm{C}$ signal, can be interpreted as follows: the carbon isotopic signature in this region is partly dependent on the relative inputs of autochthonous and allochthonous POM (expressed in the Eq. (IV) as C:N ratio), the assimilation of inorganic nutrients and the activity of planktonic organisms. The relatively low contribution of C: $\mathrm{N}$ to the variance explained by the model (4\%), is likely related to the tight correlation between POC and PON and a slope of an almost Redfield (1934) value of $\sim 7$ for their linear regression equation (Fig. 5a), which thus would represent a relative homogeneous situation

Table 4

Correlation coefficients from simple and multiple regressions of $\delta^{13} \mathrm{C}$ vs C:N ratio of POM ammonium $\left(\mathrm{NH}_{4}^{+}\right.$) and the calculated index $\varphi$.\% Variance: percentage of $\delta^{13} \mathrm{C}$ variance explained by each set of independent variables. d.f.: degrees of freedom. Coefficients with $p \leq$ 0.001 are indicated in bold.

\begin{tabular}{lllll}
\hline Dependent variable & Independent variables & $\mathrm{r}$ & \%Variance & d.f. \\
\hline$\delta^{13} \mathrm{C}$ & $\mathrm{C}: \mathrm{N}$ & 0.20 & 4 & 16 \\
& $\mathrm{NH}_{4}^{+}$ & $\mathbf{0 . 6 1}$ & 37 & 13 \\
$\varphi$ & 0.44 & 19 & 16 \\
$\delta^{13} \mathrm{C}$ & $\mathrm{C}: \mathrm{N}$ & 0.20 & 4 & 16 \\
& $\mathrm{C}: \mathrm{N}, \mathrm{NH}_{4}^{+}$ & $\mathbf{0 . 9 1}$ & 83 & 13 \\
& $\mathrm{C}: \mathrm{N}, \mathrm{NH}_{4}^{+}, \varphi$ & $\mathbf{0 . 9 6}$ & 92 & 11 \\
\hline
\end{tabular}




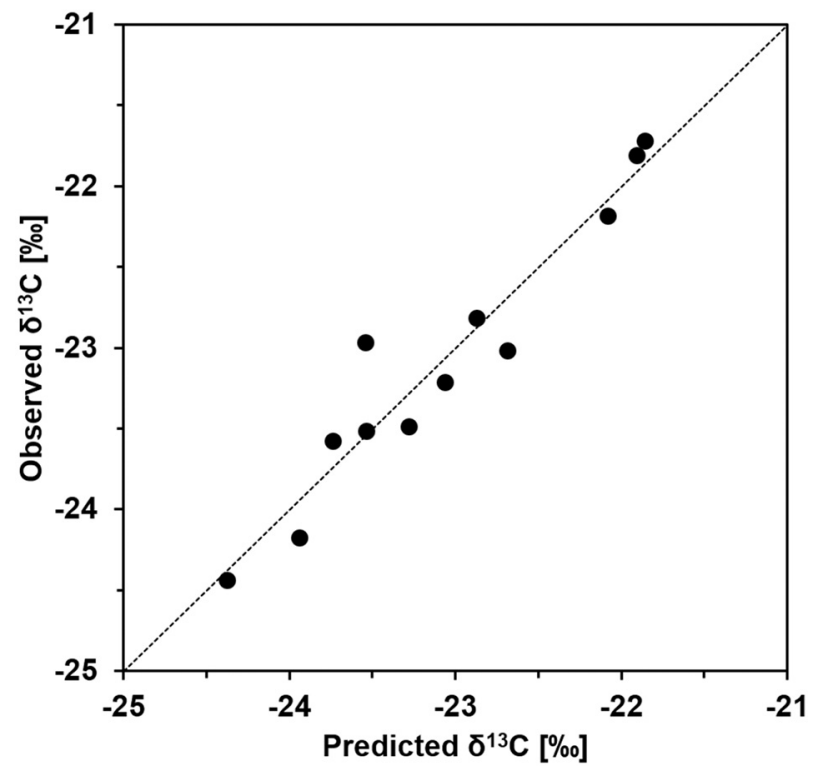

Fig. 6. Relationship of measured $\delta^{13} \mathrm{C}$ in POM vs. predicted $\delta^{13} \mathrm{C}$ values from a multiple regression with $\mathrm{C}: \mathrm{N}$ ratios, ammonium, and $\varphi$ as independent variables.

in terms of phytoplankton activity. Yet, the significant intercept of POC vs PON (3.2 $\mu \mathrm{M} \mathrm{C}$ ) and the range of variation (7.2 to 14.9) of the individual $\mathrm{C}: \mathrm{N}$ values, are likely related to the input of terrigenous detritus and/or presence of phytoplankton in different stages of senescence at some stations and thus partially explain variations in $\delta^{13} \mathrm{C}$. The variation of the C:N ratio could be considered as an indicator of phytoplankton degradation and/or mineralization (Lancelot and Billen, 1985; Martin et al., 1987; Saino, 1992).

Regarding the effect of ammonium on the isotopic signature, its uptake by phytoplankton increases $\delta^{13} \mathrm{C}$ through its effect on the $\beta$-carboxylation pathway for C fixation (Guy et al., 1989; Dehairs et al., 1997). In presence of high ammonium concentrations, the activity of enzymes regulating the intermittent assimilation of ammonium (phosphoenolpyruvate carboxylase (PEPC) and carboxykinase, PEPCK) is stimulated, which results in less isotopic discrimination and higher $\delta^{13} \mathrm{C}$ values (McCarthy and Goldman, 1979; Guy et al., 1989). This effect is strongly reflected in the model, where the inclusion of ammonium as the second variable increases the amount of explained variance to $83 \%$, contributing to successfully predict the occurrence of isotopically heavier POM. Lara et al. (2010) showed that there is evidence that natural phytoplankton can react to higher ammonium concentrations with reduced discrimination against $\delta^{13} \mathrm{C}$ even in nitrate-rich Antarctic waters dominated by diatoms (Dehairs et al., 1997). The present data set indicate that ammonium fluctuations can be relevant for explaining $\delta^{13} \mathrm{C}$ variability in general and not only in nutrient-poor, regenerative systems.

The incorporation of $\varphi$ improves the $\delta^{13} \mathrm{C}$ variance explained by the model to $92 \%$. This factor can reflect the preferential use of different $C$ sources for primary production by the various phytoplankton taxa (Mompeán et al., 2013). The inorganic C uptake by autotrophic picoplankton occurs via direct $\mathrm{HCO}_{3}^{-}$transport, while other phytoplankton (diatoms) are also able to transport $\mathrm{CO}_{2}$ derived from $\mathrm{HCO}_{3}^{-}$dehydration (Tortell and Morel, 2002). This difference would result in a larger isotopic fractionation in diatoms compared to autotrophic picoplankton (Fry and Wainright, 1991). However, dinoflagellates can utilize $\mathrm{CO}_{2}$ (Dason et al., 2004) or bicarbonate (Rost et al., 2006), in a proportion not known for this study. Additionally, HB cells are enriched in $\delta^{13} \mathrm{C}$ as result of respiration of organic substances in the Krebs cycle (Macko and Estep, 1984). Despite this complexity, the $\varphi$ parameter seems to embrace these variability sources in a way that contributes significantly to explain the $\delta^{13} \mathrm{C}$ signature of seston POM and thus deserves further investigation.
In contrast to $\delta^{13} \mathrm{C}$, the distribution of $\delta^{15} \mathrm{~N}$ shows a simple pattern of monotonous distribution, with values decreasing to the southeast, from $\sim 8$ in the inner BMW to $\sim 2$ in SAW. Considering the strong effect of ammonium on $\delta^{13} \mathrm{C}$ values, it would be expected that it also influenced $\delta^{15} \mathrm{~N}$. However, the highly significant inverse correlation between ammonium and nitrate in this sector $(\mathrm{r}=-0.79, \mathrm{n}=14, p<0.001)$ precludes the use of both nutrients as independent variables for explaining $\delta^{15} \mathrm{~N}$ variability. Several model approaches with different combinations of independent variables were tested to help understand the reason for $\delta^{15} \mathrm{~N}$ variability and the difference to $\delta^{13} \mathrm{C}$ distribution. Yet, the best fit of $\delta^{15} \mathrm{~N}$ was obtained using only the natural logarithm of the nitrate concentration as independent variable $(r=-0.92)$ in a simple linear regression, while ammonium rendered an $r=0.84$. The general inverse relationship between nitrate and $\delta^{15} \mathrm{~N}-\mathrm{POM}$ is attributed to isotopic fractionation during nitrate uptake by phytoplankton (Altabet, 2001). In order to test a possible general model for $\delta^{15} \mathrm{~N}-\mathrm{POM}$ in the western South Atlantic Ocean, values of the same relationship from Lara et al. (2010) were compared to our data (Fig. 7a).

The difference of the regression fit is likely due to the diversity of environments sampled by Lara et al. (2010), who precisely for that reason decided not to calculate the Rayleigh $(\varepsilon)$ fractionation factor. In the present work, in a diverse yet in comparison relatively reduced area, we calculated $\varepsilon$ from the inverse of the slope (Waser et al., 1998), which with $4.8 \%$ o $(r=0.92, n=14, p<0.001)$ is well in the range of values reported (4-6\%) in regions such as Southern Ocean, Subarctic Pacific, and equatorial Pacific (Altabet, 2001).

Nevertheless, strictly taken, the relation between $\delta^{15} \mathrm{~N}$ and nitrate is not a function of nitrate concentration itself, but of the fraction $(f)$ of unutilized substrate (Eq. (V)). This was also reported by Altabet and Francois (1994) for large horizontal gradients in surface nutrient concentrations, and more recently by Lara et al. (2010) for the Southern Ocean.

$f=\frac{\left[\mathrm{NO}_{3}^{-}\right] \text {observed }}{\left[\mathrm{NO}_{3}^{-}\right] \text {initial }}$

The $\delta^{15} \mathrm{~N}$ of produced PON has been assumed to be proportional to $\mathrm{F}$ (see Eq. (VI), Needoba et al., 2003), which is based on the Raleigh fractionation equation for the substrate pool (Mariotti et al., 1981).

$F=f \ln \frac{f}{(1-f)}$

Therefore, we reprocessed our $\delta^{15} \mathrm{~N}$ and nitrate data using an estimate of $f$ for the study region. Following Sigman et al. (2000) and Lara et al. (2010), we adopted a $\left[\mathrm{NO}_{3}^{-}\right]$value of $36 \mu \mathrm{M}$, considering the Upper Circumpolar Deep Water as the essentially the nitrate source for most of the Southern Ocean surface, since in comparison, continental inputs of nitrate in this region are rather low (Frangópulos et al., 2007; Torres et al., 2011). The correlation for the relationship between $\delta^{15} \mathrm{~N}$ and $\mathrm{F}$ was highly significant $\left(\delta^{15} \mathrm{~N}-\mathrm{PON}=13.0+14.5 \mathrm{~F}, \mathrm{r}=\right.$ $0.92, \mathrm{n}=14, p<0.001$, Fig. 7b).

In our data set, there is a statistically significant difference (F-test value $=4.34, \mathrm{n}=14, p<0.05$ ) between the slopes of both regression lines, with the higher value for the regression line of the present data. We speculate that the reason of this difference could be the influence of the uptake of isotopically heavier ammonium derived from runoff in the BMW internal zone. This is also reported by Paerl and Fogel (1994) for $\mathrm{N}$ inputs as sources of enhanced primary production in coastal Atlantic Ocean waters.

\section{Conclusions}

POC and PON concentrations showed clear spatial trends, decreasing from maxima in the Beagle Channel to intermediate values in Subantarctic Shelf Water and minima in Subantarctic Water. Both parameters 

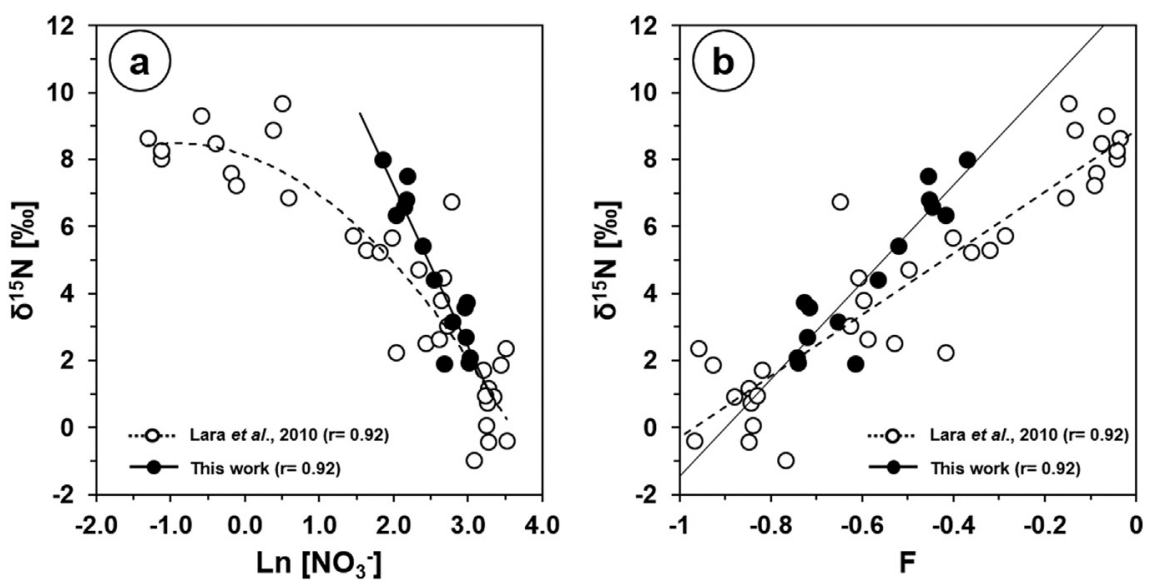

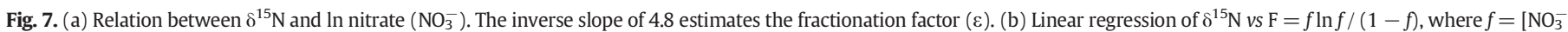

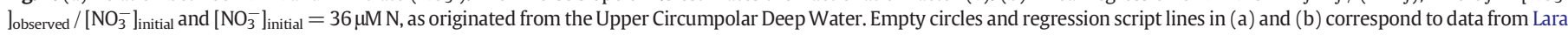
et al., 2010.

highly correlated, yet showed a wide range of C:N ratios suggesting a complex mixture of allochthonous and autochthonous components.

POC and PON highly significantly correlated with optical properties of DOM related to the diagenetic maturity of its humic components. Further, the inverse correlations of POC and PON with salinity, together with C:N variability indicate that a fraction of POM in the study area is derived from terrestrial runoff, superimposed on autochthonous components with C:N values close to Redfield (1934) ratios and plankton in different life stages.

The abundance of HB correlated highly significantly with DOC and especially with POC. This likely reflects a resource control of HB and a significant contribution of bacterial biomass to POM in the nanoparticle fraction. Further, the direct relationship between HB and specific DOM fluorescence properties suggest the bacterial uptake of fractions of the terrigenous DOM pool usually considered refractory.

The complexity of POM, as reflected in its isotopic signature, was elucidated by two models embracing most of $\delta^{13} \mathrm{C}$ and $\delta^{15} \mathrm{~N}$ variability. Compared with other works where ${ }^{13} \mathrm{C}$ variability is mainly explained by large temperature gradients, the studied region presented a narrow temperature range with a wide $\delta^{13} \mathrm{C}$ variation. This could be accounted for by a model with a degree of detail hitherto not reported in literature. A multiple regression including $\mathrm{C}: \mathrm{N}$ ratio, ammonium and the quotient between log abundance of diatoms, dinoflagellates and heterotrophic bacteria explained $92 \%$ of $\delta^{13} \mathrm{C}$ variance in this region, mostly produced by ammonium.

The $\delta^{15} \mathrm{~N}$ showed a strong inverse relationship with the fraction of unutilized nitrate. Estimated $\varepsilon$ values are similar to prior field estimates for this and other regions, which suggests dominance of nitrate uptake. However, the quantitative influence of the uptake of presumably isotopically heavier ammonium derived from runoff on the bulk $\delta^{15} \mathrm{~N}-\mathrm{POM}$ remains uncertain and requires the investigation of the isotopic composition of dissolved inorganic nitrogen in this region.

The current work presents for the first time, high-resolution models on POM isotopic composition and links the dynamics of particulate and dissolved matter in the PCES. The presented information and its comparison with data from other sectors of the Argentine shelf constitute a contribution to an approach for the understanding of the organic matter dynamics that can be potentially expanded to the entire Southwest Atlantic.

\section{Acknowledgements}

Florian Pfaff (AWI) for sampling nutrients, Gustavo A. Lovrich (CADIC) scientific leader of the expedition Patagonia Austral of the $R / V$ Puerto Deseado (CONICET-MINDEF), Argentina, Gustavo Cano (INIDEP) for providing CTD data, the $R / V$ Puerto Deseado crew for their assistance and A. Piola (Servicio de Hidrografía Naval) for bibliographical assistance with hydrographic information.

\section{Funding}

This work was financed by the binational project MINCyT-BMBF (AL/ 11/03-ARG 11/021) and partially supported by the PACES I (2009-2013) research program of the Alfred Wegener Institute as part of the Helmholtz Foundation initiative in Earth and Environment. Further contribution was made by R.J.L. through PICT 467 (AGENCIA-MINCYT).

\section{References}

Acha, E.M., Mianzan, H.W., Guerrero, R.A., Favero, M., Bava, J., 2004. Marine fronts at the continental shelves of austral South America: physical and ecological processes. J. Mar. Syst. 44, 83-105.

Almandoz, G.O., Hernando, M.P., Ferreyra, G.A., Schloss, I.R., Ferrario, M.E., 2011. Seasonal phytoplankton dynamics in extreme southern South America (Beagle Channel, Argentina). J. Sea Res. 66, 47-57.

Altabet, M.A., 2001. Nitrogen isotopic evidence for micronutrient control of fractional $\mathrm{NO}_{3}^{-}$utilization in the equatorial Pacific. Limnol. Oceanogr. 46, 368-380.

Altabet, M.A., Francois, R., 1994. The use of nitrogen isotopic ratio for reconstruction of past changes in surface ocean nutrient utilization. In: Zahn, R., Kaminski, M., Labeyrie, L., Pederson, T.F. (Eds.), Carbon Cycling in the Glacial Ocean: Constraints on the Ocean's Role in Global Change. Springer Verlag, Berlin, pp. 281-306.

Antezana, T., 1999. Plankton of southern Chilean fjords: trends and linkages. Sci. Mar. 63, 69-80.

Azam, F., Hodson, R.E., 1977. Size distribution and activity of marine microheterotrophs. Limnol. Oceanogr. 22, 492-501.

Azam, F., Fenchel, T., Field, J.G., Gray, J.S., Meyer Reil, L.A., Thingstad, F., 1983. The ecological role of water-column microbes in the sea. Mar. Ecol. Prog. Ser. 10, 257-263.

Benner, R., Kaiser, K., 2003. Abundance of amino sugars and peptidoglycan in marine particulate and dissolved organic matter. Limnol. Oceanogr. 48, 118-128.

Bianchi, A., Massonneau, M., Oliveira, R.M., 1982. Análisis estadístico de las características T-S del sector austral de la plataforma continental argentina. Acta Oceanográfica Argentina 3, 93-118.

Bujalesky, G., 2007. Coastal geomorphology and evolution of Tierra del Fuego (Southern Argentina). Geol. Acta 5, 337-362.

Carlson, C.A., 2002. Production and removal processes. In: Hansell, D.A., Carlson, C.A (Eds.), Biogeochemistry of Marine Dissolved Organic Matter. Academic Press, San Diego, CA, pp. 91-151.

Carmack, E.C., Macdonald, R.W., Jasper, S., 2004. Phytoplankton productivity on the Canadian Shelf of the Beaufort Sea. Mar. Ecol. Prog. Ser. 277, 37-50.

Cauwet, G., Sidorov, I., 1996. The biogeochemistry of Lena River: organic carbon and nutrients distribution. Mar. Chem. 53, 211-227.

Dason, J.S., Huertas, I.E., Colman, B., 2004. Source of inorganic carbon for photosynthesis in two marine dinoflagellates. J. Phycol. 40, 285-292.

Dehairs, F., Kopczynska, E.E., Nielsen, P., Lancelot, C., Bakker, D.C.E., Koeve, W., Goeyens, L., 1997. $\delta^{13} \mathrm{C}$ of Southern Ocean suspended organic matter during spring and early summer: regional and temporal variability. Deep-Sea Res. II 44, 129-142.

Emmerton, C.A., Lesack, L.F.W., Vincent, W.F., 2008. Nutrient and organic matter patterns across the Mackenzie River, estuary and shelf during the seasonal recession of sea-ice. J. Mar. Syst. 74, 741-755.

Fellman, J.B., Spencer, R.G.M., Hernes, P.J., Edwards, R.T., D'Amore, D.V., Hood, E., 2010. The impact of glacier runoff on the biodegradability and biochemical composition of terrigenous dissolved organic matter in near-shore marine ecosystems. Mar. Chem. 121, $112-122$. 
Frangópulos, M., Blanco, J.L., Hamamé, M., Rosales, S., Torres, R., Valle-Levinson, A., 2007. Análisis y diagnóstico de las principales características oceanográficas del área marina costera protegida Francisco Coloane, Informe Final Proyecto GEF-PNUD “Conservación de la Biodiversidad de Importancia Mundial a lo Largo de la Costa Chilena" November 2007 (122 pp. unpublished manuscript).

Fry, B., Sherr, E.B., 1984. $\delta^{13} \mathrm{C}$ measurements as indicators of carbon flow in marine and freshwater ecosystems. Bull. Mar. Sci. 27, 13-47.

Fry, B., Wainright, S.C., 1991. Diatom sources of ${ }^{13} \mathrm{C}$-rich carbon in marine food webs. Mar. Ecol. Prog. Ser. 76, 149-157.

Garzón-Cardona, J.E., Martínez, A., Barrera, F., Pfaff, F., Koch, B.P., Freije, R., Gómez, E., Lara R., 2016. The Pacific-Atlantic connection: biogeochemical signals in the southern en of the Argentine shelf. J. Mar. Syst. 163, 95-101.

Guerrero, R.A., Piola, A.R., 1997. Masas de agua en la plataforma continental. In: Boschi, E. (Ed.), El Mar Argentino y sus Recursos Pesqueros, Antecedentes Históricos de las Exploraciones en el Mar y las Características Ambientales. vol I. INIDEP, Mar del Plata, Argentina, pp. 107-118.

Guerrero, R.A., Baldoni, A., Benavides, B.H., 1999. Oceanographic conditions at the Southern end of the Argentine Continental Slope. INIDEP, Doc. Cient. 5, pp. 7-22.

Guy, R.D., Vanlerberghe, G.C., Turpin, D.H., 1989. Significance of phosphoenol-pyruvate carboxylase during ammonium assimilation. Plant Physiol. 89, 1150-1157.

Hamamé, M., Antezana, T., 1999. Chlorophyll and zooplankton in microbasins along the Straits of Magellan-Beagle Channel passage. Sci. Mar. 63, 35-42.

Holm-Hansen, O., Lorenzen, C.J., Holmes, R.W., Strickland, J.D.H., 1965. Fluorometric determination of chlorophyll. J. Cons. Int. Explor. Mer 30, 3-15.

Kattner, G., Becker, H., 1991. Nutrients and organic nitrogenous compounds in the marginal ice zone of the Fram Strait. J. Mar. Syst. 2, 385-394.

Kattner, G., Lobbes, J.M., Fitznar, H.P., Engbrodt, R., Nothig, E.M., Lara, R.J., 1999. Tracing dissolved organic substances and nutrients from the Lena River through Laptev Sea (Arctic). Mar. Chem. 65, 25-39.

Koroleff, K., 1983. Determination of phosphate, ammonia and silicon. In: Grasshoff, K. Ehrhardt, M., Kremling, K. (Eds.), Methods of Seawater Analyses, 2nd ed. Verlag Chemie, pp. 125-183.

Krepper, C.M., 1977. Difusión del agua proveniente del estrecho de Magallanes en las aguas de la plataforma continental. Acta Oceanográfica Argentina 1, 49-65.

Krepper, C.M., Rivas, A.L., 1979. Dinámica de las aguas costeras en el Golfo Nuevo, Parte I: Medición de corrientes con superficies derivantes. Acta Oceanográfica Argentina 2 $55-82$

Krock, B., Borel, C.M., Barrera, F., Tillmann, U., Fabro, E., Gaston, O., Almandoz, M.F., Garzón Cardona, J.E., Koch, B.P., Alonso, C., Lara, R., 2015. Analysis of the hydrographic conditions and cyst beds in the San Jorge Gulf, Argentina, that favour dinoflagellate population development including toxigenic species and their toxins. J. Mar. Syst. 148, 86-100.

Lancelot, C., Billen, G., 1985. Carbon-nitrogen relationship in nutrient metabolism of coasta marine ecosystem. Coastal marine ecosystems. Advances in aquatic microbiology. Vol. 3. Academic Press, London, pp. 263-321.

Lancelot, C., Hannon, E., Becquevort, S., Veth, C., de Baar, H.J.W., 2000. Modeling phytoplankton blooms and carbon export production in the Southern Ocean: dominant controls by light and iron in the Atlantic sector in austral spring 1992. Deep-Sea Res. I 47, $1621-1662$

Lara, R.J., Alder, V., Franzosi, C.A., Kattner, G., 2010. Characteristics of suspended particulate organic matter in the southwestern Atlantic: influence of temperature, nutrient and phytoplankton features on the stable isotope signature. J. Mar. Syst. 79, 199-209.

Longhurst, A., 1998. Ecological Geography of the Sea. Elsevier, New York

Macko, S.A., Estep, M.L.F., 1984. Microbial alteration of stable nitrogen and carbon isotopic compositions of organic matter. Org. Geochem. 6, 787-790.

Marie, D., Simon, N., Vaulot, D., 2005. Phytoplankton cell counting by flow cytometry. In: Andersen, R.A. (Ed.), Algal Culturing Techniques. Elsevier, Amsterdam, The Netherlands, pp. 253-267.

Mariotti, A., Germon, J.C., Hubert, P., Kaiser, P., Letolle, R., Tardieux, A., Tardieux, P., 1981 Experimental determination of nitrogen kinetic isotope fractionation: some principles; illustration for the denitrification and nitrification processes. Plant Soil 62, 413-430.

Martin, J.H., Knauer, G.A., Karl, D.M., Broenkow, W.W., 1987. VERTEX: carbon cycling in the northeast Pacific. Deep-Sea Res. 34, 267-285.

Mayer, L.M., Macko, S.A., Cammen, L., 1988. Provenance, concentrations and nature of sedimentary organic nitrogen in the Gulf of Maine. Mar. Chem. 25-29.

McCallister, S.L., Bauer, J.E., Canuel, E.A., 2006a. Bioreactivity of estuarine dissolved organic matter: a combined geochemical and microbiological approach. Limnol. Oceanogr. 51, 94-100.

McCallister, S.L., Bauer, J.E., Ducklow, H.W., Canuel, E.A., 2006b. Sources of estuarine dissolved and particulate organic matter; a multi-tracer approach. Org. Geochem. 37, 454-468.

McCarthy, J.J., Goldman, J.C., 1979. Nitrogenous nutrition of marine phytoplankton in nutrient-depleted waters. Science 203, 670-672.

McClelland, J.W., Holmes, R.M., Dunton, K.H., Macdonald, R.W., 2012. The Arctic Ocean Estuary. Estuar. Coasts 35, 353-368.

Mompeán, C., Bode, A., Benítez-Barrios, V.M., Domínguez-Yanes, J.F., Escánez, J., FraileNuez, E., 2013. Spatial patterns of plankton biomass and stable isotopes reflect the influence of the nitrogen-fixer Trichodesmium along the subtropical North Atlantic. J. Plankton Res. 35, 513-525.

Needoba, J.A., Waser, N.A., Harrison, P.J., Calvert, S.E., 2003. Nitrogen isotope fractionation in 12 species of marine phytoplankton during growth on nitrate. Mar. Ecol. Prog. Ser. $255,81-91$

Ohno, T., 2002. Fluorescence inner-filtering correction for determining the humification index of dissolved organic matter. Environ. Sci. Technol. 36, 742-746.

Olguín, H., Alder, V.A., 2004. Distribución de diatomeas en el Mar Argentino y océano Antártico (verano austral 2002). V Simposio. Antártico y I Latinoamericano sobre investigaciones antárticas. http://www.dna.gov.ar/CIENCIA/SANTAR04/CD/PDF/ 201BF.PDF.

Paerl, H.W., Fogel, M.L., 1994. Isotopic characterization of atmospheric nitrogen inputs as sources of enhanced primary production in coastal Atlantic Ocean waters. Mar. Biol. $119,635-645$.

Palma, S., Silva, N., 2004. Distribution of siphonophores, chaetognaths, euphausiids and oceanographic conditions in the fjords and channels of southern Chile. Deep-Sea Res. II 51, 513-535

Palma, E.D., Matano, R.P., Piola, A.R., 2008. A numerical study of the Southwestern Atlantic Shelf circulation: stratified ocean response to local and offshore forcing. J. Geophys. Res. 113, C11010. http://dx.doi.org/10.1029/2007JC004720.

Paparazzo, F.E., Alder, V.A., Schloss, I.R., Bianchi, A., Estéves, J.L., 2016. Spatial and temporal trends in the distribution of macronutrients in surface waters of the Drake Passage. Ecol. Austral 26, 027-039.

Rabalais, N.N., Turner, R.E., Justic, D., Dortch, Q., Wiseman Jr., W.J., Sen Gupta, B.K., 1996. Nutrient changes in the Mississippi River and system responses on the adjacent continental shelf. Estuaries 19, 386-407.

Redfield, A.C., 1934. On the proportions of organic derivations in sea water and their relation to the composition of plankton. In: Daniel, R.J. (Ed.), James Johnstone Memorial Volume. University Press of Liverpool, pp. 176-192.

Rost, B., Richter, K.U., Riebesell, U., Hansen, P.J., 2006. Inorganic carbon acquisition in red tide dinoflagellates. Plant Cell Environ. 29, 810-822.

Sabatini, M., Reta, R., Matano, R., 2004. Circulation and zooplankton biomass distribution over the southern Patagonian shelf during late summer. Cont. Shelf Res. 24, 1359-1373.

Saino, T., 1992. ${ }^{15} \mathrm{~N}$ and ${ }^{13} \mathrm{C}$ natural abundance in suspended particulate organic matter from a Kuroshio warm-core ring. Deep-Sea Res. I 39, 347-362.

Schlitzer, R., 2010. Ocean data view. http://odv.awi.de.

Senesi, N., Miano, N.T., Provenzano, M.R., Brunetti, G., 1991. Characterization, differentiation and classification of humic substances by fluorescence spectroscopy. Soil Sci. 152, 259-271.

Sharp, J.H., 1973. Size classes of organic carbon in seawater. Limnol. Oceanogr. 18, $441-447$.

Sigman, D.M. Altabet, M.A. McCorkle, D.C., Francois, R, Fischer, G, 2000 The $\delta^{15} \mathrm{~N}$ of nitrate in the Southern Ocean: nitrogen cycling and circulation in the ocean interior. J. Geophys. Res. 105, 19599-19614

Silva, N., Neshiba, S., 1979. Masas de agua y circulación geostrófica frente a la costa de Chile Austral. 25. Ser. Cient. Inst. Antárt. Chileno, pp. 5-32.

Sprintall, J., 2008. Long-term trends and interannual variability of temperature in Drake Passage. Prog. Oceanogr. 77, 316-330.

Thompson, G.A., Alder, V.A., 2005. Patterns in tintinnid species composition and abundance in relation to hydrological conditions of the Southwestern Atlantic during austral spring. Aquat. Microb. Ecol. 40, 85-101.

Torres, R., Frangópulos, M., Hamamé, M., Montecino, V., Maureira, C., Pizarro, G., Reid, B., Valle-Levinson, A., Blanco, J.L., 2011. Nitrate to silicate ratio variability and the composition of micro-phytoplankton blooms in the inner-fjord of Seno Ballena (Strait of Magellan, $\left.54^{\circ} \mathrm{S}\right)$. Cont. Shelf Res. 31, 244-253.

Tortell, P.D., Morel, F.M.M., 2002. Sources of inorganic carbon for phytoplankton in the eastern subtropical and equatorial Pacific Ocean. Limnol. Oceanogr. 47, 1012-1022.

Utermöhl, H., 1958. Zur vervollkommnung der quantitativen phytoplankton-methodik. Mitt. Int. Ver. Theor. Angew. Limnol. 9, 1-38.

Varela, M.M., Bode, A., González, N., Rodríguez, C., Varela, M., 2003. Fate of organic matter in the Ría de Ferrol (Galicia, NW Spain): uptake by pelagic bacteria vs. particle sedimentation. Acta Oecol. 24, S77-S86.

Verado, D.J., Froelich, P.N., McIntyre, A., 1990. Determination of organic carbon and nitrogen in marine sediments using the Carlo Erba NA-1500 Analyzer. Deep-Sea Res. I 37, 157-165.

Volkman, J.K., Tanoue, E., 2002. Chemical and biological studies of particulate organic matter in the ocean. J. Oceanogr. 58, 265-279.

Vuorio, K., Meili, M., Sarvala, J., 2006. Taxon-specific variation in the stable isotopic signatures $\left(\delta^{13} \mathrm{C}\right.$ and $\left.\delta^{15} \mathrm{~N}\right)$ of lake phytoplankton. Freshw. Biol. 51, 807-822.

Waser, N.A.D., Harrison, P.J., Nielson, B., Calvert, S.E., Turpin, D.H., 1998. Nitrogen isotope fractionation during the uptake and assimilation of nitrate, nitrite, ammonium, and urea by a marine diatom. Limnol. Oceanogr. 43, 215-224.

Zsolnay, A., Baigar, E., Jimenez, M., Steinweg, B., Saccomandi, F., 1999. Differentiating with fluorescence spectroscopy the sources of dissolved organic matter in soils subjected to drying. Chemosphere $38,45-50$. 